\section{The Spirit of the Samurai: The Kamakura Bafuku, the rise of the Bushido, and their role in diplomacy}

\author{
Armon Fouladi \\ Senior, Actuarial Science
}

Japan is undoubtedly a central component to understanding international order in Asia. Its actions from the late 1800s to the mid-1900s defined the region, and its consequences have had repercussions that have lasted into the present day (Shambaugh, 10). But where does one go to understand Japan? A place that many people would start is with the Bushido, "the code of conduct of the samurai" (Nitobe, x). In 1905, when noted writer Dr. Inazo Nitobe wanted to explain "why such and such ideas and customs prevail in Japan" (Nitobe, xii), he used the Bushido as his explanation. Introducing the Bushido as the Japan's "Precepts of Knighthood" (Nitobe, 4), he then proceeded to lay out the various values and tenets that consist of its make-up. But how exactly was the Bushido formed? Nitobe doesn't delve too deeply into that subject, saying that "It was an organic growth of decades and centuries of military career." (Nitobe, 5). But when did that growth begin? A good place to begin is with the Kamakura Bafuku (1185-1333), Japan's first military government (shogunate) which overtook from the previous Taira emperors in terms of governance (Cambridge, 46). It was during the formative years of this government that many of the Bushido's key points would be developed (Kawakami, 72). What this paper intends is to accomplish three things: to explain how the Kamakura Bafuku established itself, how the bafuku help develop the Bushido, and what effects both the Kamakura Bafuku and the Bushido have had on Japanese international relations.

The Kamakura Bafuku first emerged during the Gempei War (1180-5), a "national civil war involving substantial intraclan fighting and also pitting local against central interests" (Cambridge, 47). The primary factions involved were the Minamoto clan (led by Minamoto Yoritomo) and the Taira clan (Cambridge, 48-9). The war broke out when Yoritomo started an armed rebellion against the Taira-backed imperial court in 1180, justifying it with the claim that a prince had been left out of the imperial succession (Cambridge, 52). It was during this war that the bafuku would be formed. Although Yoritomo had been acting as a governor in his territory since the beginning of the war (Cambridge, 53), the catalyst for its official establishment would come in 1183. That year, Minamoto forces led by Yorimoto's deputies, Yoshinka and Yukiee, managed to occupy the capital of Kyoto, forcing the Taira leadership to flee (Cambridge, 55). However, Yoshinka pronounced himself the true leader of the Minamoto clan, and began to impose a dictatorship on Kyoto (Cambridge, 56). Rather than go to the capital and start a rivalry with Yoshinka, Yoritomo negotiated with the imperial court and got them to give a permanent status to his government in Kamakura (Cambridge, 56). With this, Kamakura became the preeminent peacemaker, which would carry for the next hundred and fifty years (Cambridge, 56). Following the war, Yoritomo would spend the next seven years consolidating his position, establishing the dual jito-shugo officer network in 1185 (Cambridge, 59) and being appointed the shogun in 1192 
(Cambridge, 65), a title he would hold for three years before moving to the then more prestigious office of utaisho (commander of the inner palace guards) (Cambridge, 64).

Yoritomo died in 1199, and his role in the bafuku would be slowly assumed by the Hojo clan, with their position being solidified by 1219 (Mass, 12). However, the events that made the Hojo the hegemony of the bafuku would also lead to another war between Kyoto and Kamakura in $1221^{1}$ (Cambridge, 69). Known as the Jokyu Disturbance, the war was fought swiftly and lasted two weeks (Mass, 35). Following its victory, Kamakura scattered the ex-emperor and his allies, obtained the right to interfere with high level personnel decisions, including the naming of emperors (Cambridge, 77). Following the Jokyu disturbance,

Kamakura had firmly established itself as the dominating force in the country, which would continue well into the $14^{\text {th }}$ century (Cambridge, 88)

It was during this time that what would become known as the Bushido started to form. The Kamakura Bafuku's biggest contribution to this would be in the field of Justice. Nitobe calls justice "the most cogent precept in the code of the samurai" (Nitobe, 23), and the bafuku's actions during its formative years would be a large reason why. The beginning of this was in 1183, when Kamakura gained official status from the retired emperor. With that, Kamakura established itself as the preeminent peacemaker (Cambridge, 56). Kamakura's military policing was direly needed at the time, as the Gempei war had provided cover for warriors to carry out their own private lawlessness (Cambridge, 59). Yoritomo responded to increasing pressure for order by acquiring a monopoly of power to appoint jito $^{2}$ in 1185 (Cambridge, 62). There were two results from this change. The first was that Kamakura appointed deserving vassals to jito positions that would guarantee lawfulness. The second was that a lot of the unauthorized jito, which had been common throughout the pre-Kamakura period and often engaged in criminal activities, were disciplined and dismissed (Cambridge, 62). During Yoritomo's reign, the Justice of the bafuku would develop and provide a basis for the system it would become. The basis of this system would be evidence: the bafuku's decisions on lawsuits were based on evidence provided by investigation; if there was not enough information, the case would refer to an appointed local officer (Mass, 67). The justice of the Kamakura would expand and mature considerably following the Jokyu Disturbance ${ }^{3}$, as the 1220 's would lead to a judicial revival (Mass, 93). One of the biggest changes was that both sides of a suit would be given maximum latitude, meaning that accused and the accuser would face each other as equals and the imperial court would determine the settlement (Mass, 93-4). Another reform to be enacted during this period concerned the jito, which removed the statute of limitations concerning illegally obtained land; this meant that a suit could be brought against him at any time (Mass, 107).

The bafuku also managed to ensure that it did not undermine its own position as mediator and law enforcer. This was done by ensuring that it was not brought into any disputes involving any of its vassals, thus insulating Kamakura and preventing them from bringing or answering charges themselves (Mass, 155). The Kamakura bafuku's commitment to justice was not only in its 
justice system, but it was also in its actions and legal code. The best example about this was how Yoritomo handled the case of Shigetada Hatakeyama. When a bailiff in a province in Shigetada's fiefdom was found guilty of criminal activities, Yoritomo held Shigetada accountable for his actions and had him punished, despite Shigetada being unaware of the crimes himself (Kawakami, 76). This sort of accountability was codified in the Code of Joei, and the story itself left a deep impression on samurai in the generations that followed (Kawakami, 77). It was this sort of commitment that led justice to become an integral part of the Bushido; Nitobe says that justice is "...the bone that gives firmness and stature...without [justice] neither talent nor learning can make of a human frame a samurai" (23-4). The other big contribution that the Kamakura Bafuku made to the formation of the bushido was its position and actions concerning loyalty. Loyalty was a large part of the bafuku, mostly in part because it was a very important to Yoritomo. It can be seen through the stories that have been handed down that are about loyalty, ranging from Yoritomo executing a turncoat samurai who killed one of Yoritomo's enemies as an offer of surrender (Kamikawa, 73) to a Taira vassal allowing the sons of a Minamoto vassal, who had been forced to serve the Taira, to fight for Yoritomo (Kamikawa, 74). The emphasis on loyalty was also borne out of necessity as well. During the Gempei war, loyalty was very loose; so much so that a clan could join the Minamoto cause in isolation to the actual fighting (Cambridge, 63). Yoritomo would determine the loyalty by declaring war on a clan that had remained aloof during the Gempei War, using it to consolidate his own power (Cambridge, 63). Yoritomo would also purge anyone who was even suspect of being disloyal, even his own brother (Cambridge, 65). The result is that loyalty became a firmly ingrained part of the Bushido. According to Nitobe, samurai were taught that their life was the means by which they would serve their master (93).

Both the Kamakura Bafuku and the Bushido have had an important impact on Japan's international relationships throughout history. Kamakura's involvement with diplomacy began in 1191, when the Sung Dynasty of China arrested two traders and declared that anyone travelling from Japan to China would be arrested. Japan was able to smooth over tensions concerning the issue of extradition, but the incident demonstrated that Japan had become a stronger force in East Asian history than it had before (Shoji, 400). Japan's position in international affairs became more precarious during the Hojo regency with the rise of the wako, or pirate (Hurst, 397). The wako would first appear in 1223, when they attacked the Korean ${ }^{4}$ city of Kumjo (Shoji, 405). Over the course of the next four years, the wako attacked Korea so often that the bafuku were worried that the Koryo dynasty would attack Japan (Shoji, 405). In response, Kamakura would appoint a new governor of Kyushu, who open a communique with Koryo and beheaded ninety pirates in front of a Koryo envoy (Shoji, 405-6). From there, Japan and Korea would progress to a full trading partnership (Shoji, 406). Japan would also resume trade with Sung China that would compromise of forty to fifty ships going back and forth between the two countries annually (Shoji, 408).

However, Japan issued an ordinance in 1254 limiting foreign trade, as trade had started to have adverse effects on both parties: China 
and Koryo were suffering from wako attacks and excessive outflow of coins, while Japan had to contend with a severe outflow of rice that were exacerbating ongoing famines (Shoji, 410). But these trade imbalances would soon become trivial as the Kamakura Bafuku would face its greatest test: the Mongol invasions. The lead up to the invasion began in 1266, when Kublai Khan sent a letter to Japan through Koryo that attempted to open diplomatic relations ${ }^{5}$ (Susumu, 131). The imperial court (who were the ones in charge of diplomatic relations) chose to ignore the letter, while the bafuku sent out a directive throughout the provinces telling them to prepare for a Mongol invasion (Susumu, 134-5). Mongolia would try several more times to elicit a formal response from Japan, but eventually concluded that force would be the only way to achieve their diplomatic aims (Susumu, 136-7). The actual plans for invasion began in 1273, after Mongolia had managed to conquer Sung China ${ }^{6}$ and subdue rebel elements in Korea (Susumu, 138). The invasion itself began in 1274 , with the Mongolian forces attacking Tsushima and winning the battle (Susumu, 138). The war between the two countries waged for twenty days, with both sides making retreats after fighting in Hakata in order to recuperate from losses; however, the Mongolians were caught up in a storm on their way back to Korea, and were unable to resume their mission (Susumu, 140). Following the invasion, Kamakura enacted several measures to strengthen their defenses and drew up plans to attack the Yuan bases in Korea ${ }^{7}$ (Susumu, 142-3). The next invasion would occur in 1281, as Mongolia had consolidated its power on the mainland and made conquering Japan its top priority (Susumu, 145). This time Japan was better prepared for the invasion, and was able to better repel the Yuan invaders (Susumu, 146-7). Another storm prevented the Mongols from launching another offensive, and the Yuan army lost somewhere between $60-90 \%$ of its army (Susumu, 147). A third invasion of Japan never materialized, as the Mongol empire became consumed by rebellions and inflation (Shoji, 420).

The success of repelling the Mongol invasions would remain the Kamakura Bafuku's biggest achievement in the realm of international relations, and solidified the Bushido's place in Japan's discourse of diplomacy. This can be seen by the fact that Bushido reemerges at times when Japan's place in the international order has been uncertain. The first case of this was with Nitobe. Nitobe's explanation of the Bushido (Bushido: The Soul of Japan) was published in 1905, a time when Japan was rising rapidly in the world order and confusing the West about where Japan stood (Mason, 72). Nitobe used the Bushido to explain why Japan had been able to assume such a position so quickly. According to him, "the spirit of Bushido permeated all social classes....furnishing a moral standard for the whole people" (Nitobe, 163). Nitobe then says that the Bushido is "the animating spirit, the motor force of our country" (Nitobe, 171), linking the Bushido to Japan's speedy rise and military victories that were the highlights of the Meiji Era (Mason, 72-3).

Thus, Nitobe takes the spirit of the samurai and makes it the Japanese equivalent of the knight's code of chivalry (Nitobe, 4), using it to dismiss any idea that Japan was a "childlike" country and assert that Japan was on equal footing with America and the European nations (Mason, 77). It was this interpretation of the Bushido that would 
become the "touchstone of loyalty to the state" and involved in nationalistic discourse (Turnbull, 231), and it helped establish the Bushido as the basis for calls for nationalism in times of uncertainty. This includes the present day, as Japan must deal with uneasy relations with China (Green, 204), chilly relations with South Korea (Green, 208-9), ambiguity concerning their alliance with the United States (Green, 212-3), a shrinking and aging population (Prestowitz, 36), and a stagnant economy (Prestowitz, 37-8). It is in this situation that Bushido has been used to call for a return to nationalism and militarization. In 2006, when arguing to send Japanese troops to assist the American occupation of Iraq, a member of the Diet called Japanese soldiers "[the] samurai of Japan, the nation of bushido" (quoted by Turnbull, 231). Another example is seen with the 2004 book New Bushido. In it, author Hyodo Nisohachi uses the imagery and tenements of the Bushido to create a path to national empowerment, one that is marked by Japanese possession of nuclear weapons (Mason, 83). This view of the Bushido is potent in the current international situation, as Japanese conservatives have recently been making more attempts to push for remilitarization and the abolition of Article 9 (Mason, 86). All of this harkens back to the age of Kamakura, which helped formed many of the ideals and tenets of the Bushido, which informs this current climate.

The Kamakura Bafuku may be nearly a millennium removed from the current day, but that doesn't mean that it doesn't have an impact that could be felt today. The actions of the bafuku, and its founder Minamoto Yoritomo, have had a definitive impact on the Bushido as we know it. With the Bushido such a vital component of the Japanese mindset, it is important to understand the actions and influences that created it, so that we can understand the actions taken today that determine the future.

\section{Endnotes}

1. There is no known immediate cause for this war (Cambridge, 69). The incident that is usually cited as the direct cause is the ex-emperor "strongly requesting" that two appointments be cancelled; however, this incident occurred two years prior to the actual fighting (Mass, 14).

2. Jito were vassals of the shogun who were obliged to discharge administrative services on behalf of courtier or religious landlords (Mass, xiv)

3. This happened due to the circumstances of the time rather than ideology.

Following the Jokyu Disturbance, the Kamakura Bafuku had to deal with a large number of lawsuits that complicated matters (Mass, 90).

4. It should be noted that from 918-1391, Korea was known as the Koryo dynasties (Hurst, 397). Both terms are used interchangeably by scholars writing about this time period.

5. Due to complications that prevented the messenger from entering Japan at the time, the letter did not reach Kamakura until 1268 (Susumu, 132)

6. With Kublai's conquest of China, he ended the Sung dynasty and established the Yuan dynasty (Susumu, 138).

7. It's unclear to what extent these plans were put into effect, but it is clear that they were never fully enacted (Susumu, 143). 


\section{Works Cited}

Green, Michael. "Japan's Role in Asia:

Searching for Certainty." International

Relations of Asia. 2nd ed. Plymouth:

Rowman \& Littlefield, 2014. 197-225.

Print. Asia in World Politics.

Hurst, G. Cameron, III. "Japan and East

Asia." The Cambridge History of

Japan. By Kawazoe Shoji. Vol. 3.

Cambridge: Cambridge UP, 1990.

396-446. Print.

Kawakami, Tasuke. "Bushido in Its Formative Period." The Annals of the Hitotsubashi Academy 3.1 (1952): 65-83. JSTOR [JSTOR]. Web. 02 May 2017.

Mason, Michele M. "Empowering the Would-be Warrior: Bushido and the Gendered Bodies of the Japanese Nation." Recreating Japanese Men. N.p.: U of California, 2011. N. pag. JSTOR [JSTOR]. Web. 4 May 2017.

Mass, Jeffery P. "The Kamakura Bafuku." The Cambridge History of Japan. Vol. 3. Cambridge: Cambridge UP, 1990. 46-88. Print.

Mass, Jeffrey P. The Development of Kamakura Rule, 1180-1250: A History with Documents. Vol. 3. Stanford, CA: Stanford U.P., 1979. Print.

Nitobe, Inazo. Bushido: The Soul of Japan:

An Exposition of Japanese Thought.

Rutland, VT: C.E. Tuttle, 1969. Print.
Prestowitz, Clyde V. Japan Restored: How Japan Can Reinvent Itself and Why This Is Important for America and the World. Tokyo: Tuttle, 2015. Print.

Shambaugh, David. "International Relations in Asia." International Relations of Asis. 2nd ed. Plymouth: Rowman \& Littlefield, 2014. 3-33. Print. Asia in World Politics.

Susumu, Ishii. "The Decline of the Kamakura Bafuku." The Cambridge History of Japan. Trans. Jeffrey P. Mass and Hitomi Tonomura. Vol. 3. Cambridge: Cambridge UP, 1990. 128-75. Print.

Turnbull, Stephen. "Review." Rev. of Inventing the Way of the Samurai: Nationalism, Internationalism, and Bushido in Modern Japan, by Oleg Benesch. Japan Review 2016: 230-31. JSTOR [JSTOR]. Web. 4 May 2017. 